\title{
New Index ESG Leaders \& Investment Decisions in Indonesia Relating to ESG Principles
}

\author{
Dewi Tamara ${ }^{1} \&$ Feronia Budiman ${ }^{2}$ \\ ${ }^{1}$ Binus Business School, Bina Nusantara University, Jalan Hang Lekir I No 6, Jakarta 10270, Indonesia \\ ${ }^{2}$ XQUISITE AI, Business Consultant, Jakarta, Indonesia \\ Correspondence: Dewi Tamara, Binus Business School, Bina Nusantara University, Jalan Hang Lekir I No 6, \\ Jakarta 10270, Indonesia.
}

Received: January 10, 2022

Accepted: February 20, 2022

Online Published: February 25, 2022

doi:10.5539/jms.v12n1p64

URL: https://doi.org/10.5539/jms.v12n1p64

\begin{abstract}
We investigated investors awareness of their investment decisions on the new index called ESG Leaders in the Indonesian stock exchange. We used structural equation model (SEM) to analyze the data from a survey with 103 respondents. We also used qualitative method with semi-structured interviews (SSI) from 10 industry players as respondents. We used a triangulation method to better interpret the results from SEM and SSI. We found that investment decisions were related to environmental and governance issues. The social issues, the environmental horizon, the purpose of investment and the moderating investment horizon consisting of short-term, mid-term and long term did not relate to investment decisions. The results from SSI were rather different from the survey. The investment decisions were related to environment, governance, and social issues as well, while the investment horizon was for the long term. The purpose of investment was to have a return that was higher than the market. The findings provide valuable insight for the ESG index issuer to create more awareness to attract more investors. This research was the first to explore the determinants of investment decisions on ESG Index equities. This research presents empirical evidence from retail and institution investors that they have faith in investing in the ESG Index and they are waiting for more active socialization from regulators.
\end{abstract}

Keywords: environmental social governance, ESG index leaders, investment decision, investment horizon

\section{Introduction}

Throughout 2020, the Indonesian market has experienced a rapid growth of investors. Based on PT Kustodian Sentral Efek Indonesia (KSEI), as of 30 November 2020, retail investors have recorded as many as 3.615 million investors. There was a $45.51 \%$ growth compared with the end of 2019 data. From this number, 3.582 million were individual investors while 32,183 were institutional investors (Utami, 2020). These numbers were influenced by the events of the COVID-19 pandemic. Indonesia's economic condition improved during 2020. This result is inseparable from the fiscal stimulus issued by the government throughout the COVID-19 pandemic since the third quarter of 2020 which was reflected as a surplus in exports and import adjustments (Warjiyo, 2020).

The investor composition profile in Indonesia is dominated by Millennials and Generation $\mathrm{Z}$ with an eighty percent majority (Safitri, 2021). Kunaifi and Akbar (2019) showed that the investment behavior of Millennials was influenced by their financial knowledge. It is also found by Utomo (2019) that Millennials spent 10.7 percent of their income on savings and 2 percent on investments. A study from Fidelity Charitable showed $77 \%$ of affluent Millennials are putting their money in investments that make an impact on social or environmental issues. These include companies that have a positive effect on the environment, society, and technological growth (Herlearn, 2019). There is also another effort on SRI and CSR investing known as 'impact investing'. The option is not only on investment portfolios. Publicly traded companies ought to be more critical of the stakeholders they are working with and how much environmental, social, and governance impact they create in running their operational business. The definition of a responsible company can be varied, but Millennial investors may choose to invest in companies that are not involved in substantial disputes, such as high polluting manufacturing companies or firearms companies. Impact investing here is the Millennial tendency to push the boundaries in breaking conventions. The marketplace is expected to give the double investment benefits of social 
and financial return (Chatzky \& Tuggle, 2018).

On 8th December 2020, the Indonesia stock exchange (IDX) announced thirty stocks that follow ESG (environmental, social, and governance) principles. The green index portfolio in Indonesia was officially launched in 2020. It was a product collaboration between the IDX and Sustainable Responsible Index-KEHATI to give an alternative to Indonesia's investment element options. ESG standards were used to categorize which index would be attractive as a reference for the portfolio (Rahayu, 2020). Green index portfolios have emerged as Indonesia is progressing in the industrial sectors. The mining and manufacturing sectors held the major portions.

The investment strength in Indonesia is inevitably related to GDP growth contribution by industrial sectors. Starting from manufacturing (19.7\%); wholesale, retail trade, and repair of motor vehicles and motorcycles (13\%); agriculture, forestry and fishing (12.7\%); construction (10.8\%); mining and quarrying (7.3\%); transportation and storage (5.6\%); financial and insurance activities (4.2\%); information and communication (4\%); public administration and defense, compulsory social security (3.6\%); education (3.3\%); real estate activities (2.8\%); accommodation and food service activities (2.8\%); and other services (2\%) ("Contribution to gross...", 2021). Among these sectors, mining and plantation have heightened focuses on ESG assessment. Compliance and legal obligation became factors to be considered. Not only in mining and plantation but also manufacturing. In 2019, the gross domestic product (GDP) in Indonesia was an estimated 1119.9 billion US dollars. It represented 0.93 percent of the global economy (Trading Economics, 2020). The following chart is an illustration of the GDP growth of Indonesia compared with other Asian countries.

Table 1. Asia GDP data (in US\$ billions)

\begin{tabular}{lllll}
\hline Country & $\mathbf{2 0 1 8}$ & $\mathbf{2 0 1 9}$ & Reference \\
\cline { 2 - 4 } China & 14343 & 13895 & $19-\mathrm{Dec}$ \\
Japan & 5082 & 4955 & 19-Dec \\
India & 2875 & 2713 & 19-Dec \\
South Korea & 1642 & 1721 & $19-\mathrm{Dec}$ \\
Indonesia & 1119 & 1042 & $19-\mathrm{Dec}$ \\
Taiwan & 605 & 590 & $19-\mathrm{Dec}$ \\
Thailand & 544 & 507 & 19-Dec \\
Singapore & 372 & 373 & 19-Dec \\
Malaysia & 365 & 359 & 19-Dec \\
Philippines & 377 & 347 & 19-Dec \\
\hline
\end{tabular}

\section{Literature Review}

There is a positive correlation between ESG factors and better sustainable financial performance rather than those with no ESG planning (Whelan, Atz, Van Holt, \& Clark, 2020). It compares the risk and profit proposition with a focus on SRI (socially responsible investment). Other studies elaborate on the ESG risk factors with the correlation cost of capital (equity and debt).

According to El-Ghoul, Guedhami, Kwok and Mishra (2011), companies with better CSR scores present more efficient equity financing. There are six major factors mentioned in the El-Ghoul et al. research: community; diversity; employee relations; environment; human rights and product characteristics; and contributing events. Diversity and social issues are contributing to the social characteristics aligning with El-Ghoul's theory. In recent years, younger generations such as millennials are shifting to sustainable investments which are aligned with their values ("Swipe to invest...", 2020).

Mohata's (2020) approach compared the ESG implementation in major emerging-market ESG funds (according to MSCI Indonesia ESG Leaders Index) against the conventional non-ESG counterparts. The favorable portfolio industries for investors in Indonesian market consist of banks, pharmaceuticals, and consumer companies. Mohata (2020) used the following monitoring methods: (a) ESG incorporation to decision-making, (b) the rewards with ESG incorporation, (c) sustainability risks affecting the investment, and the other way around.

ESG interference into companies' standard operation is expected to give a decent reflection of the investment path in Indonesia. Indonesian investors' behavior was categorized into two parts: expected emotion, and immediate emotion. Expected emotion is recognized when feelings that were expected to happen materialize but 
not at the time of decision-making. Immediate emotion is the emotion at the time of decision-making (Ady, 2018; Pompian, 2006). This research tested the capacity of Indonesian investors to determine if they experienced cognitive bias or psychological bias regarding ESG involvement, subject to their investment decision-making.

\section{Empirical Review and Hypotheses}

This study seeks to explore the underlying issues related to the development of the ESG Leaders Index awareness in Indonesia. It identifies the factors attracting investors as well as challenges for the development of the ESG Leaders Index in Indonesia. Investors here consisted of individual investors and organizational investors which were represented by investment analysts. The ESG was related to green economy theories. However, the implementation invites more interests such as cost efficiency, long-term planning of the companies which implementing the ESG, and other values that were considered as appealing factors.

\subsection{ESG Factors as Investment Decision Factors}

According to McKinsey, there are elements that bond of ESG factors to create value creation for the company: (1) supporting top-line growth, (2) cost efficiency, (3) minimizing legal regulation conflicts, (4) boosting employee productivity, and (5) optimizing investment and capital expenditures (Henisz, Koller, \& Nuttall, 2019). This research resulted in an alignment with at least four key points from the McKinsey study which was likely to happen because of the diversity in the country. Indonesia's demographic condition is one of the factors. Indonesia is known for a varied demographic diversity with a total population above 270 million, with more than fifty percent living on the island of Java. Targeting the respondents from this 'center' of diversity may represent some of the population for the survey. El-Ghoul (2011) mentioned that there were six dimensions related to social performance, specifically: community, diversity, employee relations, environment, human rights, and product characteristics.

Benson and Humphrey (2008) ran a test on differences between the flow-performance relation of SRI and conventional funds. Fund performance, particularly the performance of the best funds, is important to investors. Although investors are naturally profit-seekers, SRI fund research may establish searching costs. Therefore, investors are more likely to invest in funds that are familiar to conventional investors, resulting from the difficulty for SRI investors to find an alternative investment that level up their non-financial goals.

This study assesses some components from environment, social, and governance variables. Each component is a form of contribution in measuring the investors' awareness towards the non-financial factor. The purpose of this study is to evaluate investors' decision to invest by incorporating ESG factors. Some investors preferred investment as their source of income, while others utilized it as long-term harvesting (savings). Considering the speculators in the Indonesian market, short-term and middle-term investment horizons are extended into this study. Local investors utilized raising momentum in executing their investment. For eight out of ten years of performance, the impact investments showed better protection from the downside of the market. Due to this type of investor, companies are pushed to join the bandwagon (Chatzky \& Tuggle, 2018).

\subsection{Environment Factors}

Environmental protection and green management with company performance are often overlooked in traditional investment. The results of this synthesis are not well-known which results in a lack of knowledge for investors. Companies that are expected to provide environmental reports are mostly large-scale companies. Nonetheless, research by Nakamura (2011) included small and medium-sized firms in her research. It was found that environmental investment has a significant effect on small and medium firms. Dealing with green issues for large firms does not give additional appreciation to stakeholders. However, it gives room for improvement for smaller firms' company image (Nakamura, 2011).

$H_{1}=$ environmental issues are positively related to investment decisions

\subsection{Social Factor}

Social factors are associated with CSR actions. Implicit CSR is attached to a company's relationship with its' stakeholders and government within the political system. Explicit CSR is the company's program addressing the interest and issues of CSR. CSR strategy may come as CSR policies. Therefore, the issues became one of semantics rather than substance. Lastly, the stricter the regulations in a particular country, the less space there is for corporations to develop voluntary policies (Waagstein, 2010; Matten \& Moon, 2008). Implicit CSR vibrates with governance. Explicit CSR is visible and simply known as social actions from the corporations. Another consideration is the cost of equity capital which is the internal rate of return that the market applies to a firm's estimated cash flow to evaluate the current market value. If CSR affects the perceived riskiness of a firm, the firms' CSR strategy will incorporate lower equity financing costs (El-Ghoul et al., 2011). Inevitably, the social 
factors are close with governance practice.

$\mathrm{H}_{2}=$ social issues are positively related to investment decisions

\subsection{Governance Factors}

The disparity of governance settings affects the structure of capital flows. Laws, policies, customs, and norms are the rules of the game in social interactions and exchanges. Individuals and organizations are the players who are trying to maximize and protect their interests to stay in the game. Li and Filer (2007) showed a comparison of investors who are investing on the different conditions which are varied in a laissez-faire society, with transparent and efficient public rules regarding the composition of investment flows (Li \& Filer, 2007; North, 1990). The result of Li and Filer's study suggested that it ignores the difference between direct and indirect investments. A direct investment gives investors more direct and effective control, therefore better protection, especially in a governance environment where the law and accounting standards are opaque and/or negligent ( $\mathrm{Li}$ \& Filer, 2007).

$H_{3}=$ governance issues are positively related to investment decisions

\subsection{Purpose of Investment}

This variable is chosen to assess if investors in Indonesia experience cognitive bias or psychological bias which in Ady (2018) reflected the knowledge of capital markets and the firm's management actions. The possibilities provided are investments for profit orientation, investments for saving purposes usually for a longer period, and investments for trading or speculation. Ady (2018) stated that the phenomenon of cognitive bias and psychological bias existed in nearly all respondents. Our study speculates whether Indonesian investors include certain consideration such as ESG into their investment decision making.

$H_{4}=$ the purpose of investment is positively related to investment decisions

\subsection{Investment Horizon}

This research follows the model of Sultana et al. (2018) (Figure 1). The long-term horizon contributes a significant difference in ESG investments (Sultana et al., 2018). We hypothesize that the investment horizon will moderate the environment, social and governance issues when investors make investment decisions. We added three investment horizons (short, middle, and long term) to differentiate with the original model.

$H_{5 a 1}=\mathrm{A}$ long term investment horizon will strengthen the environmental issue in investment decisions

$H_{5 a 2}=\mathrm{A}$ middle term investment horizons will strengthen the environmental issue in investment decisions

$H_{5 a 3}=\mathrm{A}$ short term investment horizon will strengthen the environmental issue in investment decisions

$H_{5 b 1}=\mathrm{A}$ long term investment horizon will strengthen the social issue in investment decisions

$H_{5 b 2}=\mathrm{A}$ middle termin vestment horizon will strengthen the social issue in investment decisions

$H_{5 b 3}=\mathrm{A}$ short termin vestment horizon will strengthen the social issue in investment decisions

$H_{5 c 1}=\mathrm{A}$ long term investment horizon will strengthen the governance issue in investment decisions

$H_{5 c 2}=$ A middle termin vestment horizon will strengthen the governance issue in investment decisions

$H_{5 c 3}=$ A short term investment horizon will strengthen the governance issue in investment decisions

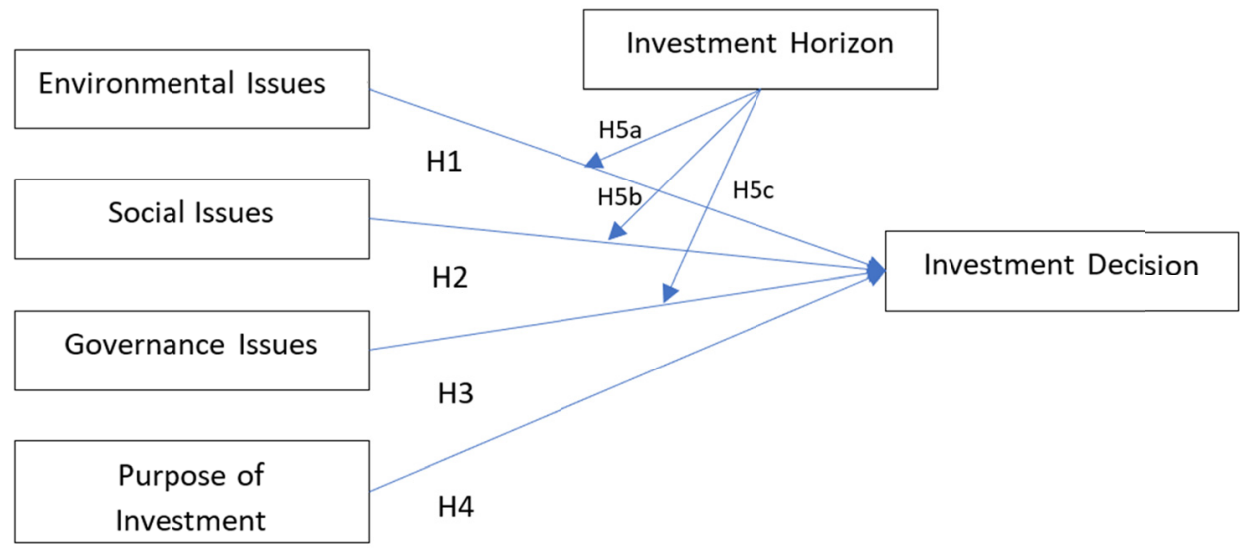

Figure 1. The model of investment decisions (Sultana et al., 2018) 


\section{Research Design}

\subsection{Quantitative Method}

This paper used a methodology that explored quantitative and qualitative assessment as well as aligned it with a theoretical application. We used a survey for the quantitative section. The survey was conducted with a Likert scale and the components were divided into several sections to determine the functions of the analysis. Each topic issue was represented on a Likert scale from 1 to 5 ( 1 was least likely to be relevant, and 5 was most likely to be relevant). Data collection for the questionnaire was conducted from April 2021 to July 2021. The sampling technique was a convenience method using the researchers' contacts. The survey was distributed to several WhatsApp groups, community meetings, academician groups, and professional colleagues. From these, we have 103 returned responses.

The indicators for the analysis are partially adapted from existing research listed in Table 2 . The environment issue was gathered by the comparison with the company's performance as well as the company's environment strategy plan with a different time scale. The social issue information was gathered from data analysis based on the focus area of CSR of the company and if the indicators were sufficient to determine the impact on the cost of equity. The governance issue base consideration was taken from Li and Filer (2007) wherein data collection was assumed to have a significant difference if companies were in a lax condition.

Table 2. Research variables and sources

\begin{tabular}{lll}
\hline Variable & Indicators & Sources \\
\hline Investment Decision & ESG as investment decision driver & Own analysis (2021) \\
Environmental Issue & Environmental investment contribution to company's performance & Nakamura (2011) \\
Social Issue & CSR problems and implications in Indonesia & Waagstein (2010) \\
& CSR effect on cost of capital & El-Ghoul et al. (2011) \\
Governance & Governance environmental impact on investment and strategic implications & Li and Filer (2007) \\
Purpose of Investment & Profitability, savings, regular income & Own analysis (2021) \\
Time Horizon & Short-term, mid-term, long-term & Sultana et al. (2018) \\
\hline
\end{tabular}

\subsection{Qualitative Method}

This research also used semi-structured interviews (SSI) as the qualitative part. The next section would be underpinning the factors of ESG investment. The focus of this area was to weigh up the scale of priorities in choosing the investment. It also reviews the investor psychology aspect towards investment decision-making. This topic elaborates its relationship with investors' behavior in Indonesia. On this level, the questions investigated the factors of ESG. Each of the factors was equalized to match with the activities from companies and to see if they were noticed by the investors. The last part was investors' awareness in selecting the investment and their perspective of ESG investment in the Indonesian market, including the acknowledgment of rewards and ESG strategy of the investment in their portfolio. The purpose of this session was to capture the acknowledgment of the respondents regarding responsiveness to ESG investing. This research also sought to determine whether they had preferences for industries.

\section{Research Results}

\subsection{Quantitative Analysis}

\subsubsection{The Respondents-SEM}

There were 82 responses from individuals and 21 responses from institutions. For both individual and institutional respondents, most of the respondents were Millennials followed by Generation X and Baby Boomers. Compared with the Millennials, these generations have earned more money as they have worked longer. Hence, they have more funds for investing. The following are the results of individual and institutional respondents. The general income for individual respondents was above 20 million Rupiah (US\$1393) per month, and most were working at the time. The main income came from salary. This meant they had an allocation of above $16.67 \%$ of their monthly income for investment. Schroders (2019) and Brett (2019) stated that Generation $\mathrm{X}$ care more about sustainability investing than Millennials. The education background was dominated by bachelor's degree $(72 \%)$ and postgraduate degree $(28 \%)$. More than half of the respondents $(64.6 \%)$ acknowledged their understanding of investing.

The corporate respondents came from companies with a personnel size of above fifty people (55\%), between 
twenty-one and fifty people (35\%), and fewer than twenty people (10\%). Illustrating the management model of the company, we sought to determine if the companies had a clear compartment for job departments. This question related to the job function. It would give a clear understanding if the respondents were directly involved in making an investment strategy. The results were varied from investment analysts $(66.7 \%)$, green index evaluators (9.5\%); and others such as CEO, banker, green index evaluator, CEO, academic researcher, and others that engaged in the operation of the company. More than seventy percent (71.4\%) of the respondents had experience of exercising formal or informal certification for investment, such as CFA, FRM, WMI (Indonesian licenses for investment managers), and others. It described their understanding in arranging the investment plans into investment decisions. $57.1 \%$ of the respondents were not directly utilizing third party vendors for ESG information suppliers such as MSCI or Sustainalytics. However, they have assigned a specific team or person to handle ESG (about 52.4\%).

\subsubsection{Research Variables—SEM}

The quantitative results were analyzed using structural equation modelling, and this research utilized SMARPLS. Table 3 shows the reliability where the Cronbach's Alpha scores are above 0.8 , except the purpose of investment variable.

Table 3. Reliability result (EXCLUDE: IVH7 \& EVI6)

\begin{tabular}{lllll}
\hline & Cronbach's Alpha & rho_A & Composite Reliability & Average Variance Extracted (AVE) \\
\hline Environmental Issue & 0.939 & 0.946 & 0.951 & 0.712 \\
Social Issue & 0.938 & 0.943 & 0.949 & 0.702 \\
Governance Issue & 0.886 & 0.890 & 0.907 & 0.523 \\
Investment Decision & 0.927 & 0.945 & 0.937 & 0.511 \\
Purpose of Investment & 0.053 & 0.073 & 0.527 & 0.341 \\
Investment Horizon & 0.855 & 0.877 & 0.888 & 0.502 \\
\hline
\end{tabular}

Table 4. R-square

\begin{tabular}{lll}
\hline & R Square & R Square Adjusted \\
\hline Investment Decision & 0.72 & 0.696 \\
\hline
\end{tabular}

Table 5. Path coefficient

\begin{tabular}{|c|c|c|c|c|c|}
\hline & $\begin{array}{l}\text { Original } \\
\text { Sample }\end{array}$ & Sample Mean & $\begin{array}{l}\text { Standard } \\
\text { Deviation }\end{array}$ & T Statistics & P Values \\
\hline Environmental Issue -> Investment Decision & 0.293 & 0.303 & 0.144 & 2.036 & 0.042 \\
\hline Social Issue -> Investment Decision & 0.107 & 0.122 & 0.154 & 0.696 & 0.487 \\
\hline Governance Issue -> Investment Decision & 0.456 & 0.442 & 0.12 & 3.82 & 0.000 \\
\hline Purpose of Investment -> Investment Decision & 0.088 & 0.088 & 0.078 & 1.124 & 0.262 \\
\hline Investment Horizon ->Investment Decision & 0.022 & 0.027 & 0.105 & 0.212 & 0.832 \\
\hline H5a_EVI-IVH -> Investment Decision & 0.036 & 0.028 & 0.135 & 0.267 & 0.79 \\
\hline H5b_SOCI-IVH -> Investment Decision & -0.182 & -0.179 & 0.165 & 1.102 & 0.271 \\
\hline H5c_GOVI-IVH -> Investment Decision & 0.262 & 0.247 & 0.107 & 2.439 & 0.015 \\
\hline
\end{tabular}

Investment Decision. Regarding ESG involvement toward investment decision making, respondents did not give solid feedback that it would directly influence their decision making as they thought they would pay a higher price for investment with ESG standards. However, they claimed to have involved environment issues, social issues, and governance in their decision-making. Moreover, respondents took companies' vision and mission alignment with their values as one of the factors whether to continue or terminate the investment. When it comes to ESG integration on the risk-adjusted, respondents assumed that it would give a positive performance against the mainstream of mutual funds.

Environment factors. The environment factor strategy was dominated by cost efficiency and higher productivity because of the company's action for environmental conservativeness. They also believed that environmental strategy was effective in supporting the existence of economic performance. The responses on environment strategy to the contribution of financial performance were not as strong as the other reasons for investment decisions due to the corporate initiatives on environmental protection policies for their operational and production activities. Investors' decision consideration was more on how the companies handled the green 
issues. They also raised concerns on how to determine the company's efforts on green management.

Social Factors. One of the most visible was how the CSR action execution in Indonesia was prone to volatile legal uncertainties, adding more administrative costs, and bureaucracy causing social and legal problems. Aligned with the research from Waagstein (2010), the conduct of social responsibility in Indonesia was associated with the independent activities of the companies against government regulations for sustainability conduct. Another likely issue was related if CSR action was effectively affecting the company's financial performance, since most professions of the respondents were in the capital market. There is a possibility that the respondents associated the question with a certain industry, such as banking. Especially because banking in Indonesia already started governance policies earlier.

Governance factor. The respondents said that government policy is highly related to employee satisfaction and rewarded with stakeholders' reaction to the reinforcement of the company's regulations. Therefore, it will give strong financial performance when a company successfully conducts a positive governance policy. Political factors are also involved with this variable as it would make an impact on investment decisions. The interpretation toward government regulation was not as impactful as the company's misconduct of business ethics. Investors believed when the company had turmoil caused by governance issues, it would certainly make a significant impact on their investment decision.

Purpose of investment. The questionnaire gave three options for investment purposes: profit orientation, savings, and regular income. Most of the responses were for profit-orientation and the investment was not relied upon as their regular income. This variable will later be discussed more in the SSI results. Relatively influenced by the individual respondents, the time horizon for investment was dominated with a period of within one year to more than three years.

Time horizon. We found similar results between the questionnaire and SSI survey that Indonesian investors were more concerned about their investment return than sustainable investing. This conclusion was close with the result from individual respondents who answered their time horizon for investment realization was within one year to two years (35.4\%), above two years (32.9\%), and less than one year (31.7\%). 


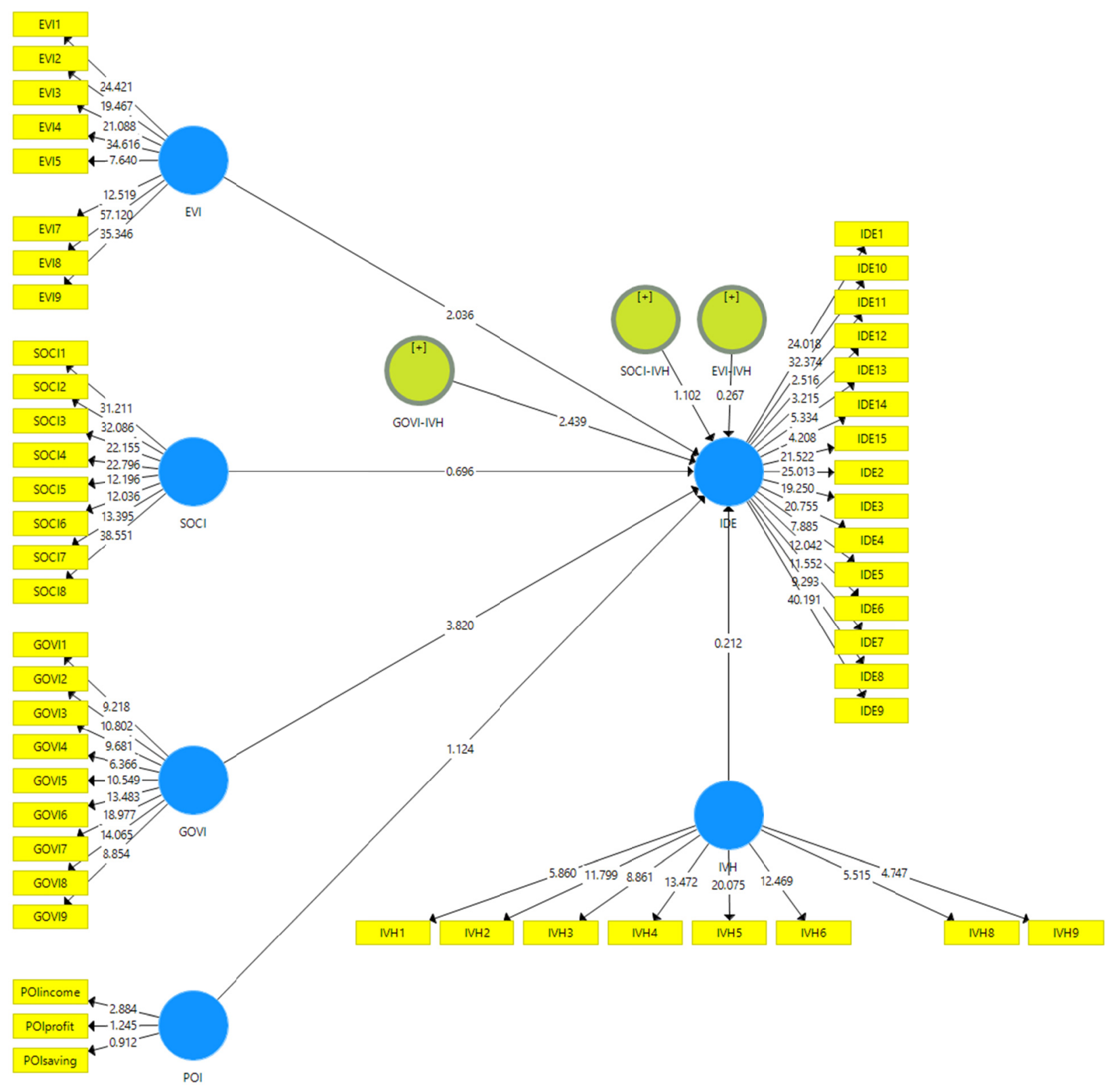

Figure 2. Path analysis

Note. EVI—Environmental Issues; SOCI—Social Issues; GOVI—Governance Issues; POI—Purpose of Investment; IVH—Investment Horizon.

\subsection{Qualitative Analysis}

The category of respondents was based on the different types of companies in the capital market industry in Indonesia. The category was divided into buy-side and sell-side. From the perspective of the buy-side, most of them were not allowed to have a direct transaction in the capital market as a part of their company's compliance policies. This was to avoid insider information spreading in the market.

\subsubsection{The Respondents-SSI}

We gathered ten respondents from eight different companies. The respondents were all experienced in the capital market industry for at least five years and most of the respondents were retail investors. Institutional respondents were those who worked in the buy-side capital market industry. Individual respondents are those from the sell-side. Four respondents represented the institutional respondents and six for the individual respondents. All respondents were based and worked in Jakarta. They were members of board of directors, managers, and senior professionals. The occupations were varied from stockbrokers, investment analysts, fund managers, fixed 
income managers, ESG analysts, and equity sales team members.

\subsubsection{Research Variables-SSI}

Table 3 shows the variables of this research with the experiences from the respondents. We found that the contents in the SSI can be categorized based on the issues per variable which resulted in different feedback of ESG descriptions. The target parameters were aided by the respondent's perspective for sustainable investment and the market conditions in Indonesia. We asked open-ended questions to enhance the insights from the respondents' experience and understanding for infant ESG development and the reaction from the market so far.

Table 6. SSI result variables category

\begin{tabular}{lll}
\hline Variables & Topic Definition & Key References \\
\hline Investment Decisions & Strategy and management factors & Own Analysis (2021) \\
Environment & Regulator involvement versus the industry & Own Analysis (2021) \\
& Influencing factors & Own Analysis (2021) \\
Social & Social act strategy & Own Analysis (2021) \\
Governance & Characteristics of governance & Own Analysis (2021) \\
Purpose of investment & Indonesian market cap was divided by industries & Own Analysis (2021) \\
& ESG as tools and initiative actions & Own Analysis (2021) \\
& The impact of ESG investment gained additional value on mature companies & Own Analysis (2021) \\
& Cons of ESG & Own Analysis (2021) \\
& ESG as an investment product & Own Analysis (2021) \\
& ESG on different industry sectors in Indonesia & Own Analysis (2021) \\
& Characteristics of Indonesian investors & Own Analysis (2021) \\
& Sustainable investing in the younger generation & Own Analysis (2021) \\
& Corporate investors' readiness and their challenges & Own Analysis (2021) \\
& Blind-side for ESG execution & Own Analysis (2021) \\
& Different time horizon definitions & Own Analysis (2021) \\
\hline
\end{tabular}

Investment Decisions. Strategy and management factors. Good management knows how to run a business; they know how to make the business sustainable and acknowledgment from the management would make it beneficial in the long run. Digital banking was subjected to the government sector but not yet to the environment and social areas. However, the governance factors on micro, small, and medium enterprises (MSME)are visibly exposed and would reach good scoring for this factor. In terms of banking strategy, the governance perspective is significant because it gets acquainted with decision-making and political variables. They should have gender equality in the working environment. The board of the management would also be up to date on the news. This action is inseparable from the management factor. The board is expected to deliver the execution. A strong board would be able to deliver shareholders' interest. The executives on the board may have vested interests. Therefore, for better control, it is suggested to pool at least fifty percent of the professionals on the board to avoid insiders. A board should represent one senior management team to balance the management. If the CEO and the chairman were the same people, they may be able to control the management. It means they will be able to control the rest of the company. There are three possible principles from this outcome:

1) The senior executive management team must have good credentials

2) A trustworthy board is the key to running the company. An expert must be able to represent shareholders on the board.

3) The risk of the business is not only to win competition but also steer towards the trends of what is happening.

Lastly, management profile analysis cannot be put up in paperwork. Although the characteristics of the management are important, the reputation of the owner is also important. These profile qualities were not easy to be summed up into a set of checklist boxes, although there is the possibility to create a thorough set of qualitative data and transform them into a quantitative set. There will be missing key points to identify the real practice compared with the form-filling. Deciding which important keys to unlock the company potential is not an instant process and requires extensive resources.

Environment Factors. Environment factors in Indonesia capital market companies were relatively under constraint. There was only one respondent who believed that good environment factors would directly have a potential financial benefit. Others assumed that the environmental strategy was somewhat destabilized for financial performance contribution. The absence of this factor on the company strategy may damage the 
company for unnecessary costs. Inevitably, the environment factors are closely related to the industry types in Indonesia.

Regulator involvement versus the industry. For coal mining companies, the risk reflected on the net income is a huge risk for the business. Not only because the business itself was opposed to the environmental sector but also mitigating the business would generate more costs. The electric vehicle industry indirectly pushed mining companies to shift to nickel mining. Due to the characteristics of the industry, the operations from mining are prone to incidents that cause increasing value on ESG scoring (high risk). Executing an environment strategy was expensive for the long term or even medium term. This factor would make a bigger impact if there was a push factor from the regulators. For nickel, for example, the production was local and efficient, so it seemed that the government was supporting the Paris Agreement for the 2050 target. Other industries such as the cement industry with its big pollution should be incentivized with environmental taxes and carbon taxes for transportation businesses. If the companies neglect this factor, they will suffer more losses, such as in penalties or judgment from society which in this case is related to social pressure. Hence, the company's image would get distorted. Nonetheless, extra taxes would cut the company's revenues. For palm oil companies, for example, land clearing by crude palm oil (CPO) companies do not create significant issues for investors. Instead, according to one respondent, it gives good capital expenditure (CAPEX). On the other hand, it is a setback for governance actions.

Influencing factors. Regulators are important to the progress of ESG in Indonesia. However, the combination values of company incentives and investment manager pressure would also accelerate the work. The regulators could also encourage the business owners to act by having eco-friendly operating assets. It requires more external factors to translate this factor into monetary results. Although their operations are sensitive to environmental factors, the dividend from mining companies is relatively high.

Social Factors. Hypothetically speaking, the social factors enhance the profit contribution which eventually increases investors' confidence and results in a lower cost of equity. According to the SSI source, CSR, which in this case represent social factors is only significant if CSR leveled up the company's image. Therefore, increased investors' confidence, improved financial performance, and lowered risks here are less information to prove CSR contributes to a lower COE. Even so, ESG implementation is limited to investors' confidence. A red plate bank that has specifically included CSR in rural and suburban areas would have better company image in society and promote the business in the area. It would also ease the business expansion process. Another industry that would have a positive impact on CSR alignment are tobacco companies. Manufacturing industries will have this factor to be concerned with if they neglect waste management procedures. In conclusion, there is no linear assurance that CSR would be aligned with a company's financial performance.

Social act strategy. ESG, in general, was often associated with CSR actions whereas the social factor is only a part of the three factors. The social strategy was close with governance actions. The translation of the practice was assumed as a formality and advertising by most of the respondents. The positive response from society would promote the company's reputation in approaching target segments. On the other hand, the incorrect strategy could lead to a bad company image which directly kills the business as the actions from CSR actions were exposed to implicit brand reputation.

Governance. Governance was one of the most pointed out during the SSI as the manner in Indonesia is prone to be hazy in regulations. Also, governance affects most companies in Indonesia. Leaders and governments are set as the benchmark for stability and consistency. Good practice of government policy would reduce unnecessary costs at the national level. Regarding the issue of 1MDB (1 Malaysia Development Berhad), the banks acted as advisors at the time and when the corruption blew up, bankers got penalized for a couple of billion dollars. If the government ruled with good governance conduct, this kind of case would not have happened, and unnecessary costs would not have to have occurred. A good governance foundation would bring good execution and deliver better long-term results. Governance performance was also an indicator for investors. If it did not perform well, investors would notice and withdraw their investment. Poor scoring in governance would also severe the social scoring. When it involved a governance factor, it becomes an explicit result.

Characteristics of governance. Governance was mentioned as explicitly and implicitly significant for Indonesian investors' decision-making. It has been a part of fundamental analysis before ESG became popular in the country. Investors have indirectly implemented this strategy in monitoring their investment. It becomes explicit when the practice has brought the company's image into the media. Therefore, it would become published information and recorded as a company's reputation.

Purpose of investment. The purpose of investment was mainly for-profit. Some claimed that they were looking 
for a sustainable investment return to hedge against inflation. Reaching a long-term capital gain as a reward of capital appreciation was also included as the nature of the company business was to manage client funds. Besides savings, other responses were to generate a return over time, to outperform the alternative index because it is cheaper, and to grow clients' wealth without sacrificing capital gain. One factor to consider in the decision was the timeline of the investment. Although the goal was to make a profit as a contribution return, the result would not be significant if the investment values plunged at the redemption time.

One of the respondents who was also an ESG analyst categorized the company's purpose of investment as to nurture the pension funds and for retail investors to achieve a financial goal. Another reason was to compete against the benchmark. Some used indices. Some compared their product performance with their peers. If the products outperformed, it added value competitiveness. There were two respondents who responded that their intention in investing was related to the growth of the investment. When the fund management companies cannot maintain growth within the short term, the product becomes unappealing for their retail investors, and if the investment is not sustainable, they lose interest from institutional clients.

Renneboog et al. (2008) suggested that investors within SRI were willing to accept a lower return to satisfy the socially responsible investment factor. In this study, respondents claimed that the competitiveness of the investment product value is to gain profit as fast as possible in the long term. Related to the time horizon of the investment, most respondents agreed to have a period of three years or more. As the purpose of investments was varied depending on clients' goals, some respondents divided the ideal timeline based on the motivation of the investors.

Indonesian market cap was divided by industries. Along with the changes in the economic structure, investors cannot always rely on the blue-chip stocks as a guarantee. When the market is expecting abnormalities in return, the market capitalization size matter regarding the magnitude of the uncertain information (Sartono, 2000). The evolution trends have been altered with some classifications from the new economic style of the digital era, with disruption to conventional businesses, and changes in long term perspective (as the long-term definition in the past is not the same length as at present). They will not make an impact within the short term which is in line with sustainability theory. The combination with ESG standards made the benefit more feasible on the corporate level compared with retail investors. Push factors from the financial institutions could contribute to efficiency for ESG implementation in the companies. Fund managers could do their role to drive the companies in implementing ESG in their operations.

ESG as tools and initiative actions. ESG-oriented investment is expected to be harvested after more than five years of investment; some even mentioned having it more than ten years. To prevent losses, some respondents preferred to cut loss within the short term to dilute the loss, or to re-evaluate the valuation. At the institutional level, the strategy for ESG-oriented investment revolves around the plans. Some already started with support from a third-party vendor. However, a third party as an information vendor is relatively costly although the information is extensive and detailed. Nonetheless, the institutional respondents are mostly agreeing to include ESG-oriented investment into their portfolio. Some put targets for the next few years, while some already put in their current investment portfolio.

The impact of ESG investment gained additional value in mature companies. Large-cap companies seemed to be more compliant because they have more resources to make sustainability reports. Small-cap companies, on the other hand, would be a concern to the business itself and not the office. They do not have sufficient resources to focus on reports. Startup companies have no obligation nor pressure to create sustainability reports. To have one requires an analysis of company conditions. In terms of execution, big companies tend to have more information. Therefore, they have a chance to gain better scoring. Smaller companies tend to have published information. Hence, they tend to have poorer scoring.

Some challenges, obstacles, and options to describe ESG execution in the Indonesian market:

1) Third-party vendors and analysts only rely on disclosed information from the companies; public information is too little, and/or there is poor access to management. Companies drop scores because they do not mention the importance of ESG assessors (Fatemi et al., 2017). Investors are starting to become aware of the ESG, but companies do not quite understand the conducts and procedures. Some companies still translate ESG as CSR actions. They also have minimum information about the ESG requirements. Nonetheless, different standards from companies and investors are troubling.

2) Insufficient liquidity to obtain more reliable information. Consequently, decisions are impulsive and close to pure speculation. Only a few investment managers could afford third-party vendors, let alone retail investors. 
3) ESG assessment process is time-consuming. It not only takes material resources but also intangible resources. Routine checking on ESG issues and trying to get a sense of how the company is managing the issues is required. ESG scoring is quantifying the qualitative data into a set of quantifiable data. Subsequently, this creates vague results on company real performance due to opaque scoring. It needs a mandatory comprehensive assessment report if the company is to mitigate the ESG issues.

4) Tricky implementation, especially in Indonesia as there is no regulated procedure on how to produce the report. There is no metric on how ESG companies are listed on the official index which create hesitance on ESG scoring reliability. There was no plan from the government to support ESG implementation. It would be more reassuring if it was supported by the government.

5) ESG is still treated as a regulation instead of education for investment. The pressure to have it implemented mostly comes from European investors rather than regulators. Also, there is no penalty for companies that fail to generate sustainability reports.

ESGL utilized Sustainalytics in forming the index. The scores reflected the riskiness of the company, the higher the score the more the risk. To get into the list, one company must score lower than thirty. Some institutional respondents have plans to launch ESG fund products based on ESGL by IDX as the benchmark. After the ESGL was launched, asset management companies were actively focusing on ESG-oriented investments. Multinational companies already started the study before the official announcement by the IDX. They were mostly European-based standards. The Parish Agreement was frequently mentioned as one of the promoting contributors of ESG. One institutional respondent already started ESG-oriented investing at the end of 2018. Nonetheless, some others are aware of ESG standards. Some asset managers have limited their investment in mining companies and added more to green energy companies. Some shifted to less polluting businesses, such as renewable energy companies.

Cons on ESG. Not everyone is on board with the ESG definition. One respondent from the institutions would prefer sustainable investment rather than ESG-oriented investment. ESG cannot guarantee long-term investment. Some doubt the implementation of ESG as it is rather too commercialized and politically unfair for some industries, such as mining, tobacco, and palm-oil plantation. Nonetheless, ESGL has one palm-oil company on its index. The implementation of an ESG-oriented plan is not simple and there are still few players to implement the practice. It requires big institutions to apply the plan to make it a success. Other countries have initiated the practice of sustainable strategy into their economic practice. For example, the USA is now following the Paris Agreement since President Joe Biden was elected in 2021. China is part of the decarbonization coalition, with zero-emission targets, and is targeting the minimal use of coal for production for the next few decades. European countries started earlier with the Paris Agreement and other sustainable practices. At the global level, there are 'Principles for Responsible Investment' (UNPRI or PRI). Working on sustainability projects is a long-term execution strategy. Therefore, as stated by one of the individual respondents, ESG practice in Indonesia requires a competitive value to sustain and attract interest in the Indonesian capital market, namely, Syariah mutual fund products.

ESG as an investment product. A similar product to sustainable investing is Syariah investing. Since 2015, the Financial Service Authority (OJK) confirmed regulations to allow investment managers to invest in Syariah mutual fund products (bonds, stocks, and currencies) in offshore securities from 51\%to 100\% (Manuturi, 2015). Before ESGL was launched, Indonesia already had SRI Kehati as a sustainable index regulator. It was benchmarked to ETF mutual funds issuance. Morgan Stanley Capital International (MSCI)and Sustainalytics are also mentioned during the interviews as ESG index benchmarks. The IDX used Sustainalytics as their index benchmark. One of the SSI respondents claimed that not all sustainable-oriented investments are slow. MSCI KLD 400 once outperformed the S\&P500. It means the public has indirectly chosen sustainable investing over the conventional index. ESG would have better propositioning if it was embedded with other values that cannot be covered with other funds.

ESG in different industry sectors in Indonesia. As mentioned earlier, ESG practice in Indonesia's capital market strategy is closely associated with the company's industry. Banking is one of the positive examples of governance practice. Mining, palm oil plantation, and tobacco are the 'opponents' of ESG procedures. Digital banking was often shown up as one of the innovative solutions for sustainability practice. The practice for bank companies is already familiar with consecutive governance policy improvements. For example, the board of management should consist of a certain number of female members; there should be an independent board member on board, and other policies related to governance. Other sectors such as mining, palm oil, and tobacco were suggested by the respondents to mitigate their business into other by-products that are acceptable for ESG 
practice procedures. Thus far, the banking industry got the best scores in Indonesia while other industries were mediocre. Large banks led the way in terms of producing sustainable reports, but the quality remains inadequate compared to Singaporean companies or the Philippines. Some ESG standards were not fair to some industries because they need more resources to come up with the same ESG data points that the analysts need to acquire.

Palm oil plantations have a Roundtable on Sustainable Palm Oil (RSPO) for global standards and Indonesian Sustainable Palm Oil (ISPO) for local standards. The Agri companies saw RSPO as a political strategy instead of an environmental action. Indirectly, the banks encouraged the companies to have RSPO and ISPO completion to get better credit rates. Some banks conclude that RSPO is more significant for European counterparts but not objective in terms of implementation in Indonesia. Nonetheless, banks as financial institutions have tried to compromise RSPO implementation and justified ISPO as sufficient to get credit financing. Globally, companies with RSPO did not perform as well other companies without RSPO. The illiquidity lessens the interest from the investors.

Usually, each sector has a problem related to their factors. For example, mining with the environment, tobacco with health, and palm oil with social and governance. According to one of the institutional respondents, the trend has evolved. The investors were not only interested to invest in socially responsible companies but also in all different sectors. All funds can accelerate to ESG standards.

Characteristics of Indonesian investors. Indonesian investors reflected the traits of the capital market as most of them were engaged in stock investing. Most of the investors were not familiar with other types of investments such as mutual funds, indexing, or any other financial products. Along with the increase of retail investors due to COVID-19, some qualities were consistent with the personality of the market. The investors demanded a quick result. They tended to have premature investment performance analysis (usually less than six months) and were only interested in easy money. They were easily affected by the crowd in the market. They had an appetite for high-risk high-return stocks. Aggressive investors did not have a proportionate investment in indexing. The investment literacy was relatively slow and at a low level. They would be looking for information from rumors, informal resources, or influencers. Not only in terms of education, but the public information was also exclusive and inadequate. Indonesian investors rely too much upon historical return data while company performance was dependent on recent activities. Investors made assumptions out of real facts. Also, only the investment managers have the privilege to foresee the assessment results from the due diligence process. To add to the challenge, the ESG investment results have not yet been proven. ESG details were still vague and to subscribe for the information from a third-party vendor was relatively expensive. Indonesian investors would prefer profit base consideration over ESG, not sustainable investing. Nevertheless, investors' aiming for profit in investment was not only occurring in Indonesia but also globally as claimed by one of the institutional respondents.

Sustainable investing in the younger generation. Some respondents believed that Millennials and the subsequent generational investors would be significant and make for a promising future. These generations were actively involved in sustainability practices; for example, their daily lifestyle consumption products were more eco-friendly, with their enthusiasm for sustainable-oriented investing. However, the practice requires more than idealism. At the end of the day, the purpose of investment is profit whether it is ESG or non-ESG as stated by the institutional respondents.

Corporate investors' readiness and their challenges. As explained earlier on how exclusive the information of ESG is in Indonesia, some corporate investors arrange their ESG team and make their own set of assessments. According to one of the respondents, Japan made a sustainable model analysis method to equalize the measurement without discriminating against certain industries. Some companies in Indonesia made their in-house measurement models analyze ESG issues. They are categorized based on events and incidents per ESG factor which required manual work. The execution of ESG was interfered with by the COVID-19 pandemic. The ESG index was once relatively strongly performing before the pandemic but the experienced a downturn.

Normally, one company would assign one to two persons per team to handle ESG analysis. The person in charge would do their analysis based on third-party vendor information. If they do not hire a third-party vendor, they either make their assessment report or rely on published information that is related to ESG issues. The team would later check if the companies engaged with ESG based on the findings and approached the companies. These teams aimed for the best financial performance that reflects the ESG product balance and performance.

Blind-side for ESG execution. There will always be uneven areas to elevate ESG performance. The application of ESG would cost the companies in some areas. For example, electric vehicle companies would have a more competitive advantage compared with the coal mining company. However, the basic feedstock for electric vehicles does not always comply with environmental factors. Lithium, a battery component of electric vehicles, 
is made of nickel and cobalt which is extracted by mineral mining.

Time Horizon. All respondents presumed duration of stock investment took more than five years. Three to five years fairly accommodated the mid-term investing. Less than three years was assumed to be short term. Institutional respondents preferred to keep it less than five years to be able to exhibit the performance of their products. Sustainable responsible investment was expected to be visible for more than ten years. One individual respondent claimed ten years is the ideal length for stocks, funds, and securities. A minimum of one year hold was necessary for stock investment as it was a monitoring period for performance evaluation. Nevertheless, stock investment requires interminable time, tedious observation, and a disciplined approach. Neglected share investment could cost the investors late execution. Premature realization is usually found when the companies hit big issues and cause the share price to plummet. Therefore, cost loss was taken. An arbitrary perspective was significant as investors were obliged to distribute, buy, and hold during their investment period.

One of the institutional respondents defined the long-term investment today as not equal to the 'old times. Three to five years could be a medium length term in the present but long term in the past. The time horizon for the investment was also used as a tool to dissect the investment strategy with different types of analysis. For more than five years of investment, fundamental analysis was required. For more frequent transactions such as monthly, weekly, or even daily; bottom-up and top-down approaches were utilized. The valuation analysis was also mentioned to keep up with the current analysis. This approach comes last because the results catch up with the current condition.

Traditionally, investors would have liked to achieve revenue growth, competitiveness among peers, match industrial trends, and perform quality management. Currently, it is to reach the terms of the accounting framework, accounting irregularity, working on capital management, and depreciation strategy. One of the interviewees focused on five areas for investment strategy:

1) Investment history

2) Owner background and profile (for governance purposes)

3) Management and the operator profile (for governance purposes)

4) Competition analysis

5) Business cycle

Another focus of the analysis was related to volatility, money management, leverage, and margin propositionally. The strategy was related to the type of investment which depends on the purpose of the investment, such as economic conditions, and the customer's (the investor's) preferences on the investment range, i.e., when the market is bull, allocate more on equity. However, it also depends about the market. Others mentioned an index on mutual funds, deposits, and savings.

\section{Discussion}

ESG implementation in Indonesia was relatively minimal in terms of socialization. Indonesian retail investors who were interested in longer-term investments are only familiar with mundane blue-chip stock investments without being acquainted with other financial instrument investments. They not only have limited learning on stock investments but also financial investment in general. They are also not familiar with the ESG concept. The lack of education on sustainability investing and contributing factors for the companies were involved. There are ways to stimulate investment socialization, one of which is through e-commerce platforms. Combining digitalization and sustainable investing would gain investors' interest to diversify their investments, especially if the investment could start as low as 100,000 Rupiah (\$7). Targeting the mid-income level would accelerate the process as they have more room for investment. They were expected to bring an average investment of as much as 20 to 30 million Rupiah $(\$ 1,396$ to $\$ 2,094)$ per year. Increasing awareness of superfunds was also suggested. Other alternative methods of support such as tutorial videos and presentations to agents and distributors may also gain more awareness. The role of asset managers, investment managers, fund managers, and other professionals was expected to transfer ESG concept knowledge to the investors especially for retail investors, although the process involved extra work to promote the ESG concept; asset managers may release products and educate the investors.

Start-ups. Start-up companies might not be interested in the ESG concept for it offers different goals. They might not prepare a budget for ESG because they might think it was not related to them. Their focus would be more on business expansion, making a profit, and reducing costs. Indirectly, business owners might have already implemented the ESG procedure through their practices. For example, they may incentivize the workers by 
giving fair working conditions. The key point here is to maintain the basics: human capital development; talent retention; and attraction.

Financial service roles. The agents and distributors from financial services were necessary for ESG implementation. However, in terms of the institutions, they were expected to be the driver for the index in Indonesian market capitalization, in terms of lending. The checklist for credit scoring could be adjusted in terms of ESG standards. Normally banks have breakdowns of the loan book, mainly coming from mining and the rest coming from the supply chain of mining. ESG could play its role here.

ESG investment conditions in Indonesia. There is no direct investment yet on ESG, apart from through the IDX with its' ESGL 30. SRI Kehati may have served the concept for sustainable investing, but ESG is still limited. From the perspective of the company, if the small and middle caps have no plans for ESG strategy, there would be always a gap with big-cap companies. Public companies would be more exposed to ESG procedures than private companies. Therefore, they will feel more pressure in implementing the ESG concept. Private companies' pressure would come from the customers. They are more focused on supply chain compliance instead of ESG reporting. Retail investors and small-size companies are not ready or socialized enough. However, setting up role model companies as ESG compliance benchmarks would ease the process of ESG socialization. As mentioned earlier the government should tax companies that are not compliant with ESG. Incentivizing companies that actively comply with ESG would persuade other companies to join the crowd.

Real engagement or stewardship should be the end goal for ESG investing. Insufficiently informed companies would tend to terminate ESG in the middle of the process and it would not bring any benefit but wasted resources. In retail investors' case, they were not aware of the benefit of ESG investment. Investment in equity shares was mainly driven by retail investors and they were not quite ready yet for ESG. The government involvement for the aggressive retail customer was welcomed as for the moment there was policy from the financial services authority (Otoritas Jasa Keuangan) for asymmetrical auto-reject of $7 \%$ for loss. However, there is also a $20 \%$ potential gain for retail investors which incites reactive actions from some retail investors.

\section{Conclusion}

This research aimed to identify the investment decisions on a new index called ESG Leaders. ESG concepts and principles are increasingly gaining popularity. Investors in Indonesia, both individuals and institutions were looking to invest in this new index. This research was among the first to identify factors of investment decisions in the ESG index base.

Empirical findings supported the investors' investment decisions for including the ESG index in their portfolio. ESG principles of the companies included in the index attracted the investors as their contribution pertaining to the environment, society, and overall governance. The investment horizon itself showed an indifferent attitude, whereby short-term was the objective from individual investors, mid and long-term are for individual investors.

The findings provide insight to authorities of exchanges to be more active in socializing the ESG Index to increase the awareness of investors. These investors have faith in macroeconomic and microeconomic conditions in Indonesia, looking back at the huge youth demography and the improvement its per capita income, in participating in environment, social and governance indexed types of investment.

\section{References}

Ady, S. U. (2018). The Cognitive and Psychological Bias in Investment Decision-Making Behavior: Evidence from Indonesian Investor's Behavior). Journal of Economics and Behavioral Studies, 10(1), 86-100. https://doi.org/10.22610/jebs.v10i1(J).2092

Arli, D., \& Tjiptono, F. (2014). Does corporate social responsibility matter to consumers in Indonesia? Social Responsibility Journal, 10(3). https://doi.org/10.1108/SRJ-01-2013-0007

Auer, B. R. (2014). Do Socially Responsible Investment Policies Add or Destroy European Stock Portfolio Value? Journal of Business Ethics, 135, 381-397. https://doi.org/10.1007/s10551-014-2454-7

Bassen, A., \& Kovacs, A. M. (2008). Environmental, Social and Governance Key Performance Indicators from a Capital Market Perspective. ZeitschriftfürWirtschafts und Unternehmensethik, 9(2), 182-192. https://doi.org/10.5771/1439-880X-2008-2-182

Benson, K. L., \& Humphrey, J. E. (2008). Socially Responsible Investment Funds: Investor Reaction to Current and Past Returns. Journal of Banking \& Finance, 32, 1850-1859. https://doi.org/10.1016/j.jbankfin.2007.12.013

Białkowski, J., \& Starks, L. (2016). SRI Funds: Investor Demand, Exogenous Shocks, and ESG Profiles. 
Retrieved from https://ir.canterbury.ac.nz

Brett, D. (2019, September 17). Gen Xers care more about sustainability than millennials. Schroders. Retrieved from https://www.schroders.com/en/uk/private-investor/insights/global-investor-study/gen-xers-care-more-aboutsustainability-than-millennials/

Bursa Efek Indonesia luncurkanindeks ESG Leaders. (2020, 14 December). MSN. Retrieved from Bursa Efek Indonesia luncurkan indeks ESG Leaders (msn.com)

Caplan, L., Grisworld, J. S., \& Jarvis, W. F. (2013). From SRI to ESG: The Changing World of Responsible Investing. Commonfund Institute. Retrieved from https://files.eric.ed.gov//fulltext/ED559300.pdf

Chatzky, J., \& Tuggle, K. (2018, November 14). How millennials are changing the way we invest. NBC News. Retrieved from https://www.nbcnews.com/better/business/how-millennials-are-changing-way-we-invest-ncna935381

Chen, J. (2020, March 11). Tilt Fund Definition. Investopedia. Retrieved from https://www.investopedia.com

Cheng, B., Ioannou, I., \& Serafeim, G. (2012). Corporate Social Responsibility and Access to Finance. Harvard Library. https://doi.org/10.1002/smj.2131

CNN Indonesia. (2021, January 18). Kronologi ANTAM Digugat 817 Miliar, Setara 11 Ton Emas. Retrieved from https://www.cnnindonesia.com/ekonomi/20210118112326-92-595041/kronologi-antam-digugat-rp817-milia r-setara-11-ton-emas

Cornfield, J. (2020, July 14). Millennials look to make a social impact with their investing dollar, study finds. CNBC.

https://www.cnbc.com/2020/07/14/millennials-look-to-make-a-social-impact-with-their-investing-dollar.ht $\mathrm{ml}$

Diaz-Sarachaga, J. M., Espino, \& Fresno, D. J. (2018). Is the Sustainable Development Goals (SDG) index an adequate framework to measure the progress of the 2030 Agenda? Sustainable Development, 1-9. https://doi.org/10.1002/sd.1735

Duuren, E. V., Plantinga, A., \& Scholtens, B. (2015). ESG Integration and the Investment Management Process: Fundamental Investing Reinvented. J Bus Ethics, 138, 525-533. https://doi.org/10.1007/s10551-015-2610-8

El-Ghoul, S., Guedhami, O., Kwok, C. C. Y., \& Mishra, D. R. (2011). Does corporate social responsibility affect the cost of capital? Journal of Banking \& Finance, 35, 2388-2406. https://doi.org/10.1016/j.jbankfin.2011.02.007

Fatemi, A., Glaum, M., \& Kaiser, S. (2017). ESG performance and firm value: The moderating role of disclosure. Global Finance Journal, 38, 45-65. https://doi.org/10.1016/j.gfj.2017.03.001

Fink, L. (2021, January). Larry Fink's 2021 Letter to CEOs. Black Rock. Retrieved from https://www.blackrock.com/corporate/investor-relations/larry-fink-ceo-letter

Formánková, S. et al. (2019). Millennials' Awareness and Approach to Social Responsibility and Investment-Case Study of the Czech Republic. MDPI. https://doi.org/10.3390/su11020504

Giamporcaro, S., \& Pretorius, L. (2015). Sustainable and responsible investment (SRI) in South Africa: A limited adoption of environmental criteria. Investment Analysts Journal, 75, 2012. https://doi.org/10.1080/10293523.2012.11082541

Hassel, L., \& Semenova, N. (2013). The Added Value of ESG/SRI on Company and Portfolio Levels -What Can We Learn from Research? Sustainable Investment Research Platform, 13-2.

Heng, S. K. (2020, December 24). Ace Hardware Indonesia ACES.JK ACES IJ; Indo ESG series: low-hanging fruit. Nomura. Retrieved from http://www.nomuranow.com/research

Henisz, W., Koller, T., \& Nuttall, R. (2019). Five ways that ESG creates value. McKinsey. Retrieved from https://www.mckinsey.com/business-functions/strategy-and-corporate-finance/our-insights/five-ways-that-e sg-creates-value

Herlean, G. (2019, April 2). How Millennials are Challenging the Future of Investment. Forbes. Retrieved from https://www.forbes.com/sites/forbesfinancecouncil/2019/04/02/how-millennials-are-changing-the-future-ofinvestment/?sh=7fc3bd $3742 \mathrm{fe}$

Huang, J., Wei, K. D., \& Yan, H. (2007). Participation Costs and the Sensitivity of Fund Flows to Past 
Performance. Journal of Finance, 62(3), 1273-1311. https://doi.org/10.1016/j.jbankfin.2007.12.013

Indonesia GDP. (2019, December). Trading Economics. Retrieved from https://tradingeconomics.com

Indonesia Stock Exchange. (2020). Guide for IDX ESG Leaders (Version 1.1, November 2020) (Appendix of IDX Announcement No.: Peng-00363/BEI.POP/11-2020 date 30 November 2020). Indonesia Stock Exchange. Retrieved from https://www.idx.co.id/media/9407/appendix-index-guide-idx-esg-leaders-v1_1.pdf

Intan, N., \& Yolandha, F. (2020, December 28). KSEI catat Investor Pasar Modal Tumbuh 45,51 Persen. Republika. Retrieved from https://republika.co.id/berita/qm17e9370/ksei-catat-investor-pasar-modal-tumbuh-4551-persen

Jassem, S., Azmi, A., \& Zakaria, Z. (2018). Impact of sustainability balanced scorecard types on environmental investment decision-making. Sustainability, 10, 541. https://doi.org/10.3390/su10020541

Knox, S., \& Maklan, S. (2004). Corporate Social Responsibility: Moving Beyond Investment Towards Measuring Outcomes. European Management Journal, 22(5), 508-516. https://doi.org/10.1016/j.emj.2004.09.009

Kocmanová, A., \& Dočekalová, M. (2013). Construction of the economic indicators of performance in relation to environmental, social, and corporate governance (ESG) factors. Acta Univ. Agric. Silvic. MendelianaeBrun., 60, 195-206. https://doi.org/10.11118/actaun201260040195

Kunaifi, A., \& Akbar, A. N. (2019). Financial Knowledge and Millennials Investing Behaviours in Indonesia. JurnalSosialHumoniora. https://doi.org/10.12962/j24433527.v0i01.5768

Li, S., \& Filer, L. (2007). The effects of the governance environment on the choice of investment mode and the strategic implications. Journal of World Business, 42, 80-98. https://doi.org/10.1016/j.jwb.2006.11.006

Loebiantoro, I. K., Eaw, H. C., \& Annuar, N. (2021). The Existence of Behavioral Biases and Personality Traits in Explaining the Effect of Fundamental and Technical Analysis to Investment Performance in Indonesia Stock Exchange. JurnalIntelek, 16(1). https://doi.org/10.24191/ji.v16i1.380

Manuturi, V. (2015, November 19). OJK Allows Mutual Funds to Invest Offshore. Jakarta Globe. Retrieved from https://jakartaglobe.id/business/ojk-allows-shariah-mutual-funds-invest-offshore/

McIntosh, M. J., \& Morse, J. M. (2015). Situating and Constructing Diversity in Semi-Structured Interviews. Global Qualitative Nursing Research. https://doi.org/10.1177/2333393615597674

Mohata, T. (2020, December 12). Indonesia Equity Strategy: Europe ESG push and why it matters. Nomura. Retrieved from http://www.nomuranow.com/research

MSCI ESG Research. (2020, March). Swipe to invest: the story behind millennials and ESG investing. Retrieved from https://www.msci.com/documents/10199/07e7a7d3-59c3-4d0b-b0b5-029e8fd3974b

Nagy, Z., Cogan, D., \& Sinnreich, D. (2013). Optimizing Environmental, Social and Governance Factors in Portfolio Construction: Analysis of three ESG-tilted strategies. MSCI ESG Research. https://doi.org/10.2139/ssrn.2221524

Nagy, Z., Kassam, A., \& Lee, L. E. (2015). Can ESG Add Alpha? An Analysis of ESG Tilt and Momentum Strategies. The Journal of Investing Summer, 25(2), 113-124. https://doi.org/10.3905/joi.2016.25.2.113

Nakamura, E. (2011). Does Environmental Investment Really Contribute to Firm Performance? An Empirical Analysis Using Japanese Firms. Eurasian Business Review, 1(2), 91-111.

Nanayakkara, N. S., Nimal, P. D., \& Weerakoon, Y. K. (2019). Behavioural Asset Pricing: A Review. International Journal of Economics and Financial Issues, 9(4), 101-108. https://doi.org/10.32479/ijefi.8190

Pollard, J. L., Sherwood, M. W., \& Grand, R. (2018). Establishing ESG as Risk Premia. Journal of Investment Management, 16(1), 1-12.

Prasidya, Y. (2020, August 28). The Rise of the retail investor: A new force in Indonesia's pandemic-hit stock market. The Jakarta Post. Retrieved https://www.thejakartapost.com/news/2020/08/27/the-rise-of-the-retail-investor-a-new-force-in-indonesiaspandemic-hit-stock-market.html

Rahayu, A. C. (2019). Analis: Green Index yang baruakanmenarikjadiacuanportofolio. Kontan. Retrieved from https://investasi.kontan.co.id 
Rahman, M., Isa, C. R., Dewandaru, G., Hanifa, M. H., Chowdury, N. T., \& Sarker, M. (2020). Socially responsible investment sukuk (Islamic bond) development in Malaysia. Qualitative Research in Financial Markets, 12(4). https://doi.org/10.1108/QRFM-09-2019-0117

Renneboog, L., Horst, J. K., \& Zhang, C. (2008). Socially responsible investments: Institutional aspects, performance, and investor behaviour. Journal of Banking \& Finance, 32, 1723-1742. https://doi.org/10.1016/j.jbankfin.2007.12.039

Ruggie, J. G., \& Middleton, E. K. (2019). Money, Millennials and Human Rights: Sustaining 'Sustainable Investing'. Global Policy. University of Durham and John Wiley \& Sons, Ltd. https://doi.org/10.1111/1758-5899.12645

Safitri, K. (2021, September 2). HinggaAgustus 2021, Jumlah Investor SahamMencapai 2.6 Juta SID. Kompas. Retrieved from https://money.kompas.com/read/2021/09/02/163651826/hingga-agustus-2021-jumlah-investor-saham-menc apai-26-juta-sid?page=all

Santosa, P. W., \& Santoso, P. W. (2019). Does Exchange Rate Volatility cause Overreaction in the Capital Market? Evidence from Indonesia. International Journal of Finance and Accounting, 8(3), 80-87. Retrieved from https://www.researchgate.net/publication/337567862_Does_Exchange_Rate_Volatility_cause_Overreaction _in_the_Capital_Market_Evidence_from_Indonesia/link/5ddea21c299bf10bc32b81e9/download

Sartono, A. (2000). Overreaction of The Indonesian Capital Market: is Market Rational. GadjahMada International Journal of Business, 2(2).

Setiya, T. (n.d.). Facts of Indonesia. Retrieved January 31, 2021 from https://factsofindonesia.com/the-total-of-how-many-islands-in-indonesia-are-populated

Sievanen, R., Rita, H., \& Scholtens, B. (2012). The Drivers of Responsible Investment: The Case of European Pension Funds. J Bus Ethics, 117, 137-151. https://doi.org/10.1007/s10551-012-1514-0

Silvola, H., \&Landau, T. (2021) ESG Analysis Tools for Assessing Listed Shares. In Sustainable Investing. Palgrave Macmillan, Cham. https://doi.org/10.1007/978-3-030-71489-5_5

Soegiarto, H., \& Irawan, H. (2019). China takes the stage on ESG; what Indonesian companies can do to cope. Deutsche Bank.

Statista 2022. (2019). Contribution to gross domestic product of Indonesia in 2020, by industry. Retrieved on January 31, 2021, from https://www.statista.com/statistics/1019099/indonesia-gdp-contribution-by-industry/

Sultana, S., Zulkifli, N., \& Zainal, D. (2018). Environmental, Social and Governance (ESG) and Investment Decision in Bangladesh. Sustainability, 10, 1831. https://doi.org/10.3390/su10061831

Tahir, S. (2020, December 15). Perhatian! Ada IndeksBaru ESG Leaders, Ini 30 Sahamnya. CNBC Indonesia. Retrieved from https://www.cnbcindonesia.com/market/20201215070716-17-209079/perhatian-ada-indeks-baru-esg-leader s-ini-30-sahamnya/2

Tempo.co. (2021, March 11). Indonesia's Unemployment Rate Increases due to Pandemic: Minister Ida Fauziah. Retrieved from https://en.tempo.co/read/1441103/indonesias-unemployment-rate-increases-due-to-pandemic-minister-ida-f auziah\#

Thakur, M. (2021). What is Free Float Market Capitalization? Retrieved on January 28, 2021, from https://www.wallstreetmojo.com/free-float-market-capitalization/

Townsend, B. (2020). From SRI to ESG: The Origins of Socially Responsible and Sustainable Investing. The Impact of Journal \& ESG Investing, 1(1) 10-25. https://doi.org/10.3905/jesg.2020.1.1.010

Trotman, K. T., \& Bradley, G. W. (1981). Associations Between Social Responsibility Disclosure and Characteristics of Companies. Accounting, Organization and Society, 6(4), 355-362. https://doi.org/10.1016/0361-3682(81)90014-3

Utami, D. N. (2020, December, 23). Jumlah Investor di Akhir 2020 HampirSentuh 4 Juta Investor. Market Bisnis. Retrieved

from https://market.bisnis.com/read/20201223/7/1334804/jumlah-investor-di-akhir-2020-hampir-sentuh-4-juta-in vestor 
Utomo, W. P. (2019). Indonesia Millennial Report 2019. IDN Research Institute. Retrieved from https://efaidnbmnnnibpcajpcglclefindmkaj/viewer.html?pdfurl=https $\% 3 \mathrm{~A} \% 2 \mathrm{~F} \% 2 \mathrm{Fcdn}$.idntimes.com $\% 2 \mathrm{Fco}$ ntent-documents\%2Findonesia-millennial-report-2019-by-idn-times.pdf\&clen=40494605\&chunk=true

Velte, P. (2017). Does ESG Performance have an impact on financial performance? Evidence from Germany. Journal of Global Responsibility, 8(2), 169-178. https://doi.org/10.1108/JGR-11-2016-0029

Waagstein, P. R. (2010). The Mandatory Corporate Social Responsibility in Indonesia: Problems and Implications. Journal of Business Ethics, 98, 455-466. https://doi.org/10.1007/s10551-010-0587-x

Warjiyo, P. (2020, December 22). Economic stability maintained and recovery process underway (part 1). The Jakarta Post. Retrieved from https://www.thejakartapost.com/academia/2020/12/21/economic-stability-maintained-and-recovery-process -underway-part-1.html

Whelan, T., Atz, U., Van Holt, T., \& Clark, C. (2021). ESG and Financial Performance: Uncovering the Relationship by Aggregating Evidence from 1,000 Plus Studies Published between 2015-2020. NYU Stern, Center for Sustainable Business. Rockefeller Asset Management. Retrieved from https://www.readkong.com/page/esg-and-financial-performance-uncovering-the-relationship-9522431

Yawika, M. K., \& Handayani, S. (2019). The Effect of ESG Performance on Economic Performance in the Industry in Indonesia. Journal of International Business and Economics, 7(2), 112-121. https://doi.org/10.15640/jibe.v7n2a12

Yu, S., Gao, S., \& Sun, H. (2016). A dynamic programming model for environmental investment decision-making in coal mining. Applied Energy, 166, 273-281. https://doi.org/10.1016/j.apenergy.2015.09.099

\section{Copyrights}

Copyright for this article is retained by the author, with first publication rights granted to the journal.

This is an open-access article distributed under the terms and conditions of the Creative Commons Attribution license (http://creativecommons.org/licenses/by/4.0/). 